\title{
Production of tumour necrosis factor during murine cutaneous leishmaniasis
}

\author{
HEIDRUN MOLL, KERSTIN BINÖDER, \\ CHRISTIAN BOGDAN, WERNER SOLBACH \& \\ MARTIN RÖLLINGHOFF \\ Institut für Klinische Mikrobiologie, Universität Erlangen-Nürnberg. \\ Erlangen, Federal Republic of Germany
}

Accepted for publication 20 March 1990

\begin{abstract}
Summary We have assessed the role of tumour necrosis factor- $\alpha$ (TNF) during cutaneous leishmaniasis and demonstrated that significant levels of TNF were released by spleen cells from infected mice after in vitro restimulation with Leishmania major promastigotes. Spleen cells from both genetically resistant and genetically susceptible mice were equally capable of producing TNF. After challenge with bacterial endotoxin, TNF activity could also be demonstrated in the serum of $L$. major-infected mice and the titres correlated with the course of cutaneous disease in susceptible and resistant mice. TNF did not exert a direct leishmanicidal effect in vitro. Furthermore, our study indicated that macrophages are the source of $L$. major-induced TNF activity and that its elicitation is dependent on the presence of $T$ cells. These findings suggest that TNF acts in concert with other cytokines produced during $L$. major infection and that its role depends on the composition of $T$ cell subsets and cytokines present.
\end{abstract}

Keywords: tumour necrosis factor- $\alpha$, cytokines, Leishmania major, immunoregulation, mice

\section{Introduction}

Tumour necrosis factor- $\alpha$ (TNF, cachectin) is a multifunctional cytokine that is produced predominantly by macrophages and exerts diverse effects on a wide variety of cells including tumour cells, lymphocytes, fibroblasts and endothelial cells (Beutler \& Cerami 1989). TNF has been shown to mediate inflammation caused by endotoxin of Gramnegative bacteria (Carswell et al. 1975) and to influence macrophage interaction with protozoan parasites (DeTitto, Catterall \& Remington 1986, Kongshavn \& Ghadirian 1988, Wirth \& Kierszenbaum 1988) and intracellular bacteria (Bermudez \& Young 1988). The role of TNF has been analysed in a variety of infectious diseases and conflicting

Correspondence: Dr H.Moll, Institut für Klinische Mikrobiologie, Universität Erlangen-Nürnberg, Wasserturmstr. 3, 8520 Erlangen, FRG. 
results have been obtained from these studies. TNF levels are frequently increased in patients with kala-azar (Scuderi et al. 1986) or with severe Plasmodium falciparum infections and recent experimental work has supported the view that TNF may account for the pathological features of murine cerebral malaria (Clark et al. 1987, Grau et al. 1987). In the serum of patients with meningococcal septicaemia, high TNF levels correlated with a negative outcome of disease (Waage, Halstensen \& Espevik 1987). On the other hand, plasma levels of TNF were low in lepromatous leprosy as compared to tuberculoid leprosy patients (Silva \& Foss 1989) and a protective role of TNF has been reported for murine infections with Bacillus Calmette-Guérin (BCG; Kindler et al. 1989), Listeria monocytogenes (Havell 1987, Nakane, Minagawa \& Kato 1988) and Escherichia coli (Cross et al. 1989).

Leishmania major, the cause of cutaneous leishmaniasis, is a digenetic protozoan parasite alternating between the promastigote form in the sandfly vector and the obligatory intracellular amastigote form that resides in phagolysosomes of the mammalian host's macrophages. The infected macrophage is supposed to be the target of the immune response mediated by $L$. major-specific T cells (Louis \& Milon 1987). The course of disease in mice depends on the strain of animals used. Mice of genetically resistant inbred strains (e.g., C57BL/6) can control the infection with lesions healing completely, whereas genetically susceptible mice (e.g., BALB/c) develop progressive disease with lethal outcome. T cell-deficient nude mice of all genotypes are highly susceptible (Handman, Ceredig \& Mitchell 1979). Since macrophages are an important effector component in host resistance to $L$. major, we considered it of interest to investigate the production of TNF in $L$. major-infected healer and non-healer mice and to correlate the level of TNF release with the state of disease. In the studies to be presented, we show that infection with $L$. major primed mice for release of TNF in viro, in response to endotoxin, as well as in vitro, in response to either endotoxin or L. major promastigotes. In addition, it was found that the $L$. major-induced TNF activity of macrophages was dependent on the presence of $T$ cells.

\section{Materials and methods}

\section{MICE}

Female mice of the inbred strains BALB/c and C57BL/6 were used at an age $5-12$ weeks. Female athymic BALB/c nu/nu (nude) mice were 5-7 weeks of age at the commencement of experiments. All mice were purchased from Charles River Breeding Laboratories (Sulzfeld, FRG) and, during experimentation, were maintained under conventional conditions in an isolation facility.

\section{CULTURE MEDIUM}

RPMI 1640 medium (GIBCO, Karlsruhe, FRG) was supplemented with L-glutamine ( $2 \mathrm{mM})$, Hepes buffer $(10 \mathrm{~mm}), \mathrm{NaHCO}_{3}(7.5 \%), 5 \times 10^{-5} \mathrm{M} 2$-mercaptoethanol, penicillin $(100 \mu \mathrm{g} / \mathrm{ml})$, gentamycin $(160 \mu \mathrm{g} / \mathrm{ml})$ and $10 \%$ fetal calf serum (Seromed, Berlin, FRG) selected for low endotoxin content $(4 \cdot 2 \mathrm{ng} / \mathrm{ml}$ as determined by the supplier). 
PARASITES, INFECTION OF MICE AND ASSESSMENT OF LESIONS

The origin and propagation of the $L$. major isolate has been described in detail elsewhere (Solbach, Forberg \& Röllinghoff 1986a). The cloned virulent line used for this study was confirmed to be L. major by isoenzyme analysis (Dr D.Evans, London School of Hygiene and Tropical Medicine, London, UK) and was maintained by passage in BALB/c mice. Promastigotes were grown in vitro in blood agar cultures (Solbach et al. 1986b). Stationary-phase promastigotes were washed in phosphate-buffered saline (PBS) and $2 \times 10^{6}$ organisms were injected in a volume of $50 \mu$ intradermally (i.d.) on the dorsum of the mouse close to the base of the tail. Lesion scores were determined at regular intervals according to the following system: $0=$ no lesion or healed scar; $1=$ small swelling (up to 5 $\mathrm{mm}$ in average diameter); $2=$ large swelling (more than $5 \mathrm{~mm}$ in average diameter) or open lesion of less than $5 \mathrm{~mm}$ in average diameter; $3=$ open lesion of $5-10 \mathrm{~mm}$ in average diameter; $4=$ open lesion greater than $10 \mathrm{~mm}$ in diameter and/or obvious metastases.

\section{INDUCTION OF TNF PRODUCTION IN VIVO}

At various times after infection with L. major or 10 days after infection with $2 \times 10^{7}$ BCG (Connaught Laboratories, Willowdale, Canada), groups of 3 mice were intravenously (i.v.) injected with $10 \mu \mathrm{g}$ LPS from $E$. coli serotype 055:B5 (Difco, Detroit, USA) in a volume of $0.1 \mathrm{ml}$. After $2 \mathrm{~h}$, mice were bled and serum was collected for subsequent determination of TNF activity.

\section{INDUCTION OF TNF PRODUCTION IN VITRO}

$T$ cells were separated from whole spleen and lymph node cell suspensions by passage through a nylon wool followed by a Sephadex G10 (Pharmacia. Uppsala, Sweden) column. For preparation of macrophages, spleens were cut into small pieces and were digested in a solution containing $1.5 \mathrm{mg} / \mathrm{ml}$ pronase (Boehringer, Mannheim, FRG) and $100 \mu \mathrm{g} / \mathrm{ml}$ DNase (Boehringer) under continuous rotation $\left(50 \mathrm{rpm}, 37^{\circ} \mathrm{C}, 30 \mathrm{~min}\right.$ ) in 90-mm tissue culture dishes (Greiner, Nürtingen, FRG), as described elsewhere (Hockertz et al. 1986). After erythrocyte lysis and washing (in the presence of DNase), 4$5 \times 10^{7}$ cells in $15 \mathrm{ml}$ culture medium were incubated in a tissue culture dish for $24 \mathrm{~h}$ ( $37^{\circ}$, $5 \% \mathrm{CO}_{2}$ ). Subsequently, the non-adherent cells were carefully removed from the monolayer of adherent cells by repeated washing with warm $\left(37^{\circ} \mathrm{C}\right)$ culture medium. The dishes were put on ice for $1 \mathrm{~h}$ to allow the collection of the adherent population which was virtually free of lymphocytes as judged by subsequent staining with fluoresceinated antiThy- 1 and anti-immunoglobulin antibodies. More than $95 \%$ of the adherent cells were shown to be macrophages by May-Grünwald-Giemsa and non-specific esterase staining.

For induction of TNF production, unselected spleen cells or purified $T$ cells or macrophages were obtained from untreated or $L$. major-infected mice. $5 \times 10^{6}$ spleen cells or $2 \times 10^{6} \mathrm{~T}$ cells were placed into 2-ml cultures (Nunc, 143982; Wiesbaden, FRG) and $1 \times 10^{5}$ macrophages were cultured in flat-bottom microtitre plates (Nunc, 167008) in a volume of $0.2 \mathrm{ml}$. The cells were stimulated with the mitogens LPS $(10 \mu \mathrm{g} / \mathrm{ml})$ or concanavalin A (Con A; $2.5 \mu \mathrm{g} / \mathrm{ml}$; Serva, Heidelberg, FRG) or with live L. major promastigotes $\left(1 \times 10^{6} / \mathrm{ml}\right)$ collected during the stationary phase of growth. After $6 \mathrm{~h}$ (mitogen stimulation) or $24 \mathrm{~h}$ ( $L$. major stimulation) of culture, supernatants were

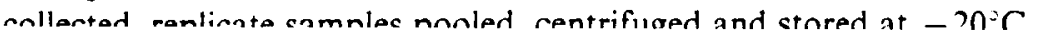




\section{ASSESSMENT OF TNF ACTIVITY}

For the detection of biologically active TNF and lymphotoxin (LT, TNF- $\beta$ ) in sera and culture supernatants, cells of the fibrosarcoma line WEHI 164, which are highly sensitive to the cytolytic effects of both cytokines, were used as target cells (Okuno et al. 1986). In the presence or absence of a polyvalent antiserum specific for murine TNF (100 neutralizing units (U); Genzyme, Boston, USA), samples were tested for cytotoxic activity by incubating serial dilutions ( $50 \%$ initial concentration) with $2 \times 10^{4}$ WEHI 164 cells and actinomycin D $(0.5 \mu \mathrm{g} / \mathrm{ml}$; Sigma, Deisenhofen, FRG) in a volume of $0.2 \mathrm{ml}$ in flat-bottom microtitre plates. For quantification of viable cells, the colorimetric MTT (3(4,5-dimethylthiazol-2-yl)-2,5-diphenyl-tetrazolium bromide) assay was used (Tada et al. 1986). After $24 \mathrm{~h}$ incubation, MTT (Sigma) was added ( $10 \mu \mathrm{l}$ of MTT solution of $5 \mathrm{mg} / \mathrm{ml}$ in PBS), and $5 \mathrm{~h}$ later, cultures were supplemented with $100 \mu \mathrm{l}$ of $10 \%$ sodium dodecyl sulphate (SDS) in $0.01 \mathrm{~N} \mathrm{HCl}$ and incubated overnight at $37^{\circ} \mathrm{C}$. The absorbance was measured with a microplate reader (MR 700; Dynatech, Denkendorf, FRG), using a test wavelength of $550 \mathrm{~nm}$ and a reference wavelength of $670 \mathrm{~nm}$. In this assay, the optical density (OD) values are inversely related to the degree of cytotoxic activity mediated by TNF. A standard titration of recombinant murine TNF ( $r T N F$, kindly provided by $\mathrm{Dr}$ G.R.Adolf, Ernst-Boehringer-Institut, Vienna, Austria) at dilutions ranging from $2 \mathrm{U} / \mathrm{ml}$ to $0.016 \mathrm{U} / \mathrm{ml}$ was set up with each assay $(1 \mathrm{U}=38.5 \mathrm{pg}$ rTNF as determined by the supplier in a bioassay with murine tumour cells). The data were subjected to probit analysis, compared to the standard curve, and the activity of each sample was expressed in units of TNF. The detection threshold of the colorimetric assay for TNF activity was 0.5 $\mathrm{U} / \mathrm{ml}$.

\section{Results}

\section{EFFECT OF TNF ON GROWTH OF L. MAJOR IN VITRO}

Previous studies have shown that rTNF is able to inhibit the growth of trypanosomes in vitro even at very low concentrations (Kongshavn \& Ghadirian 1988). To determine whether TNF also affects the in vitro proliferation of L. major, rTNF at concentrations ranging from $10^{1}$ to $5 \times 10^{3} \mathrm{U} / \mathrm{ml}$ was added to promastigote cultures and the parasite content was determined 3 days later using the colorimetric MTT assay (Table 1). It was found that the growth of $L$. major promastigotes was not altered by any of the TNF concentrations tested. Thus, TNF does not seem to exert a direct leishmanicidal effect.

\section{TNF ACTIVITY IN SERA OF L. MAJOR-INFECTED MICE}

We determined the TNF level in serum of either genetically susceptible or genetically resistant mice infected with $L$. major in order to correlate the capacity to produce TNF with the course of cutaneous disease. At various intervals after i.d. infection with L. major, susceptible BALB/c and resistant C57BL/6 mice were challenged i.v. with LPS. Sera were collected $2 \mathrm{~h}$ later and pooled for determination of the TNF activity of individual experimental groups. The results in Figure 1 show that TNF activity could be detected in sera of both BALB/C and C57BL/6 mice infected with $L$. major. Serum TNF titres of 
Table 1. Effect of rTNF on the growth of L. major promastigotes in vitro

\begin{tabular}{rc}
\hline & $\begin{array}{c}\text { OD values } \\
\text { mean } \pm \text { s.d. }\end{array}$ \\
\hline 5000 & $0.376 \pm 0.033$ \\
1250 & $0.368 \pm 0.031$ \\
310 & $0.377 \pm 0.024$ \\
80 & $0.370 \pm 0.013$ \\
10 & $0.322 \pm 0.029$ \\
0 & $0.353 \pm 0.013$ \\
\hline
\end{tabular}

* Blood agar cultures containing $L$. major promastigotes $\left(1 \times 10^{5}\right.$ in $\left.0.1 \mathrm{ml}\right)$ and various concentrations of rTNF were incubated at $26^{\circ} \mathrm{C}$ for 3 days. Subsequently, $0.1 \mathrm{ml}$ of parasite suspension were collected from each culture and were transferred to fresh microculture wells in order to quantify the living promastigotes by using the colorimetric MTT assay. Each value represents the mean \pm s.d. of triplicate cultures.

OD: optical density.

BALB/c mice increased with progressing infection, whereas those of C57BL/6 mice peaked at a much lower level. In a control experiment with BCG-infected C57BL/6 mice challenged with LPS, high titres of TNF could be demonstrated showing that mice of this strain are well capable of releasing this factor. The results obtained with BCG-treated mice are in agreement with other reports showing that C57BL/6 mice are high-responders and BALB/c mice are low-responders with respect to endotoxin-induced TNF production after BCG priming (Haranaka, Satomi \& Sakurai 1984). LPS-induced production of TNF was dependent on prior infection with $L$. major or BCG since no significant amounts of TNF could be detected in sera of uninfected mice (data not shown). In the absence of LPS stimulation, L. major-infected mice of either strain failed to elicit TNF activity (data not shown). Athymic nude mice infected with $L$. major elicited only low titres of LPSinduced serum TNF (80-300 U/ml) even though they develop progressive disease. This TNF activity was in the same order of magnitude as that detected in sera of uninfected nude mice challenged with LPS (data not shown).

In order to discriminate between the cytotoxic factors TNF and LT, both of which have the capacity to lyse WEHI 164 cells in vitro, we added an antiserum specific for TNF to the in vitro assay used for determination of TNF titres. The TNF activity detected in the serum samples was completely neutralized in the presence of this antiserum (data not shown). These results show that TNF alone but not LT accounts for the LPS-induced cytotoxic factor in the serum of L. major-infected mice. 

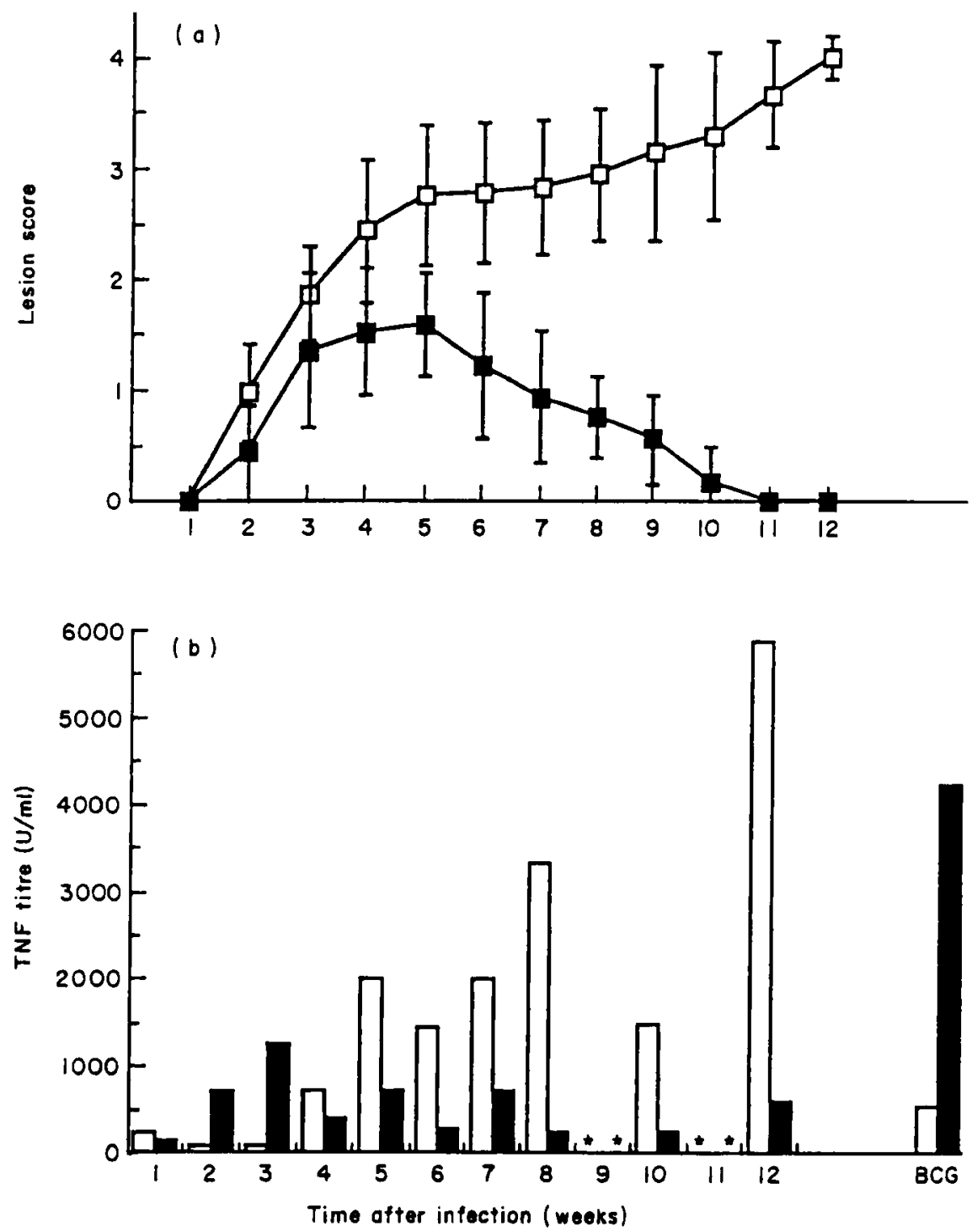

Figure 1. Course of lesion development (a) and LPS-induced TNF activity (b) in sera of BALB/c ( $\square$. open bars) and C57BL/6 ( $\square$, closed bars) mice infected with $2 \times 10^{6} \mathrm{~L}$. major promastigotes. At various intervals after i.d. infection, cutaneous lesion scores were determined (a) and mice were injected with $10 \mu \mathrm{g}$ LPS i.v. (b). In a control experiment, mice were infected with $2 \times 10^{7}$ BCG and were challenged with LPS 10 days later. Blood was collected $2 \mathrm{~h}$ after administration of LPS, and serum TNF titres were determined according to the cytotoxicity against WEHI 164 cells in the colorimetric MTT assay. Three mice were used for each time point. Arithmetic means of the cutaneous lesion scores (as defined in Materials and methods) are given with the respective standard errors (a). The standard errors in the TNF assays were consistently below $5 \%$ (b). "Not tested. 
TNF PRODUCTION OF CELLS FROM L. MASOR-INFECTED MICE IN RESPONSE TO MITOGEN STIMULATION IN VITRO

At various times of infection with $L$. major, unseparated spleen cells or purified spleen macrophages from BALB/c and C57BL/6 mice were stimulated with LPS in vitro. After 6 $\mathrm{h}$, which was found to be the time of maximal LPS-induced TNF release, culture supernatants were collected and assayed for TNF activity. As it has been observed for other infectious diseases (Havell 1987, Tarleton 1988), the TNF levels detected after in vitro stimulation were generally much lower than those found in the serum of infected mice challenged with LPS. However, they were significantly above background and reproducible in numerous experiments. In cultures of whole spleen cells, the TNF response was more pronounced for $\mathrm{BALB} / \mathrm{c}$ than for $\mathrm{C} 57 \mathrm{BL} / 6$ mice infected with L. major and increased with severeness of disease (Figure 2a). These results confirm the data obtained with serum samples from infected mice. On the other hand, purified macrophages from infected BALB/c and C57BL/6 mice did not differ consistently in their ability to release LPS-induced TNF (Figure $2 b$ ). This suggests that the enhanced capacity of TNF production of $L$. major-infected BALB/c mice is caused by the increased proportion of macrophages in these animals (Modabber 1987; C.Bogdan and W.Solbach, unpublished observations). As it was the case for the serum samples, all the TNF activity in culture supernatants was totally abrogated by anti-TNF antiserum (data not shown).

$T$ cells purified from the spleens and lymph nodes of $L$. major-infected mice failed to

release TNF upon in vitro stimulation with the mitogen Con A (Figure $2 \mathrm{c}$ ). Their functional integrity was confirmed by the ability to produce interleukin 2 (IL-2; data not shown), as it was expected from mitogen-stimulated $T$ cells obtained from primed mice. These results provided evidence for macrophages being the predominant source of TNF in mice with cutaneous leishmaniasis.

TNF PRODUCTION OF CELLS FROM L. MAJOR-INFECTED MICE IN RESPONSE TO IN VITRO RESTIMULATION WITH L. MAJOR

In view of the finding that infection with L. major can prime mice for LPS-induced TNF production both in vivo and in vitro, studies were carried out to determine the capacity of these animals to release TNF in response to in vitro restimulation with $L$. major. In analogy to the in vitro assay system described above, spleen cells or macrophages were prepared at various intervals after infection and were cultured with live $L$. major promastigotes in vitro. Culture supernatants collected after $24 \mathrm{~h}$ of incubation were found to contain a maximum of $L$. major-induced TNF activity. The results presented in Figure 3 show that spleen cells from both infected $\mathrm{BALB} / \mathrm{c}$ and $\mathrm{C} 57 \mathrm{BL} / 6$ mice were able to release TNF in response to $L$. major alone (in the absence of mitogen). We could not detect consistent differences in the TNF levels produced by those mice. However, no TNF activity could be detected in cultures of purified macrophages (data not shown) even though the same preparations of macrophages were very well able to produce TNF upon LPS challenge (see above, Figure 2b). Therefore, we conclude that the elicitation of TNF activity in response to $L$. major infection is dependent on the presence of $\mathrm{T}$ cells. 

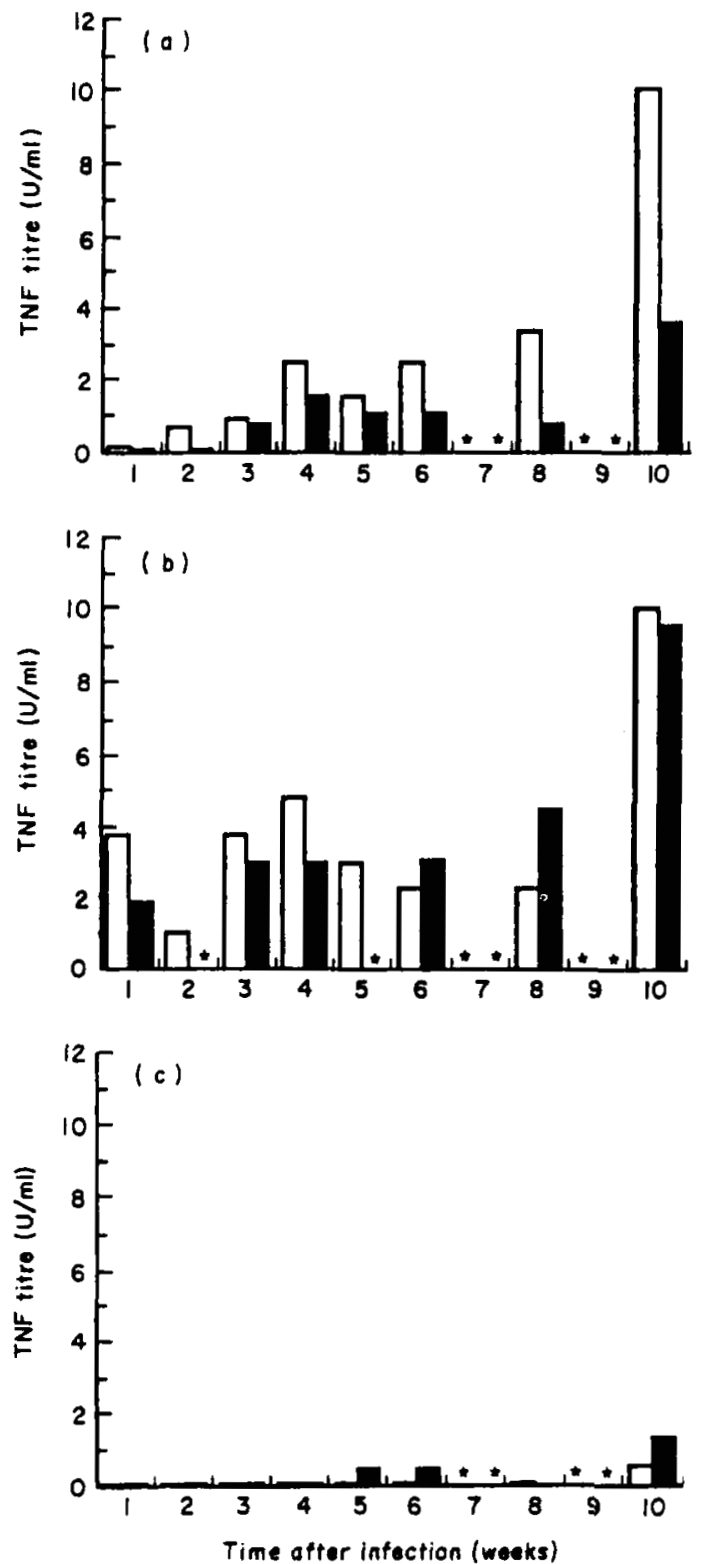

Figure 2. TNF activity of cells from infected BALB/c (open bars) and C $57 B L / 6$ (closed bars) mice in response to mitogen stimulation in vitro. At various times after i.d. infection with $2 \times 10^{6} \mathrm{~L}$. major promastigotes, mice were killed and $5 \times 10^{6}$ unselected spleen cells in 2 -ml cultures (a) or $1 \times 10^{5}$ purified macrophages in cultures of $0.2 \mathrm{ml}$ (b) were stimulated with $10 \mu \mathrm{g} / \mathrm{ml}$ of LPS. Cultures $(2 \mathrm{ml})$ of $2 \times 10^{6}$ purified T cells from spleens and lymph nodes (c) were stimulated with $2.5 \mu \mathrm{g} / \mathrm{ml}$ of Con A. After $6 \mathrm{~h}$ incubation, supernatants were collected and assayed for TNF activity in the MTT assay. The s.d. were consistently below $5 \%$. ${ }^{*}$ Not tested. 


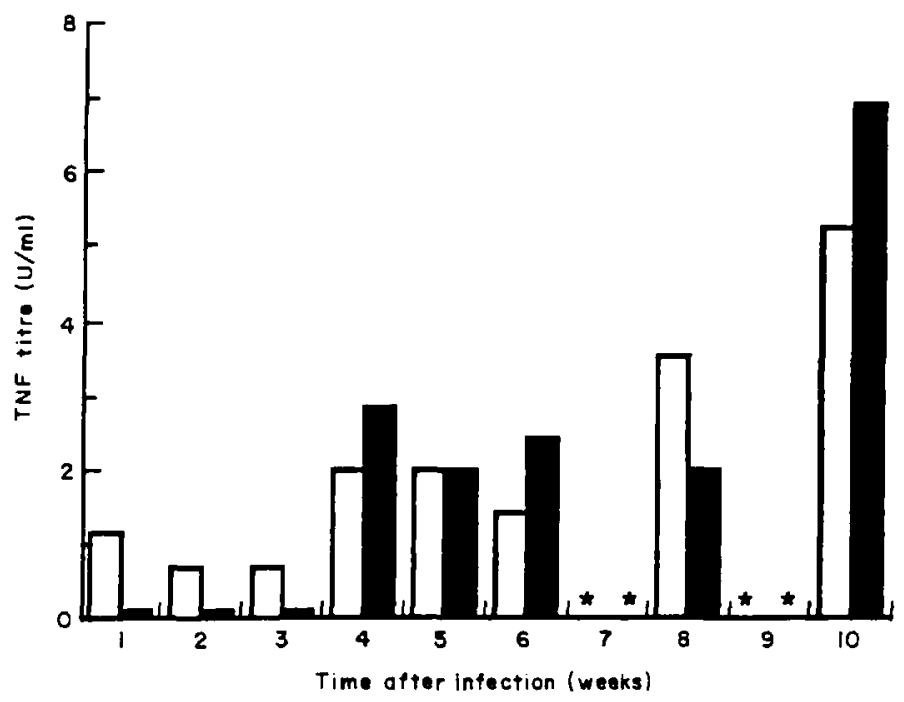

Figure 3. TNF activity of cells from infected BALB/c (open bars) and C57BL/6 (closed bars) mice after in vitro restimulation with $L$. major. At various intervals after i.d. infection of mice with $2 \times 10^{6}$ $L$. major promastigotes, $5 \times 10^{6}$ unselected spleen cells in $2-\mathrm{ml}$ cultures were stimulated with $L$. major promastigotes $\left(1 \times 10^{6} / \mathrm{ml}\right)$. After $24 \mathrm{~h}$ incubation, supernatants were collected and assayed for TNF activity in the MTT assay. The s.d. were consistently below $5 \%$. * Not tested.

\section{Discussion}

Significant serum levels of TNF are generally induced by an initial priming step and a subsequent secondary stimulus, usually bacterial LPS (Carswell et al. 1975, Beutler \& Cerami 1989). Upon challenge with LPS, serum TNF activity could be detected in both genetically susceptible BALB/c and genetically resistant C57BL/6 mice infected with $L$. major. However, the TNF titres were markedly higher in BALB/C than in C57BL/6 mice and increased with progression of disease in susceptible mice. Thus, the LPS-induced TNF activity in the serum appeared to correlate with severeness of cutaneous leishmaniasis. On the other hand, the TNF activity in sera from athymic BALB/c nude mice challenged with LPS was not significantly increased after infection with $L$. major, even though these animals are susceptible to the disease. However, previous reports have already pointed out that nude mice differ from euthymic mice in their ability to produce TNF (Haranaka et al. 1984). Even in chronically infected BALB/c mice, no serum TNF activity could be detected in the absence of an LPS stimulus. Similar findings have been reported for other bacterial and protozoal infections (Nakane et al. 1988, Tarleton 1988). However, our observation that spleen cells from infected mice are able to release TNF after in vitro restimulation with live $L$. major promastigotes strongly suggests that infection with L. major results in the production of TNF in vivo in the absence of an LPS challenge. The $L$. major-induced TNF release may be restricted to the sites of infection and may therefore not be detectable in the serum, as it has been observed in mice infected with BCG (Kindler et al. 1989). Alternatively, the levels of TNF secreted under natural conditions may be lower than those induced by LPS and the rapid clearance of TNF from 
the circulation (Beutler, Milsark \& Cerami 1985) may thus prevent its detection in the serum of L. major-infected mice.

While this paper was in review, a report was published that suggested a beneficial effect of TNF on leishmaniasis (Titus, Sherry \& Cerami 1989). The TNF was proposed to originate from $T$ cells in infected mice and to in hibit parasite replication in macrophages. In the present study, however, we showed that TNF activity was detected exclusively in mitogen-stimulated cultures containing purified macrophages but not in those of purified $T$ cells. Therefore, the TNF activity elicited by $L$. major-infected mice is likely to be produced by macrophages. Furthermore, we demonstrated that TNF alone, in the absence of interferon- $\gamma$ (IFN- $\gamma$ ) or LPS, failed to activate macrophages for killing of $L$. major amastigotes (Bogdan et al. 1990).

After in vitro stimulation with live $L$. major promastigotes, TNF activity could only be detected in cultures of unseparated spleen cells but not in those of purified macrophages from infected mice. These results favour the notion that the presence of $T$ cells is required for the elaboration of TNF activity by macrophages in response to L. major infection, an interpretation which is supported by our finding that athymic nude mice infected with $L$. major elicited only low titres of serum TNF. Some $T$ cell products such as IL-3, granulocyte-macrophage colony-stimulating factor (GM-CSF) or IFN- $\gamma$ are known to stimulate the differentiation of macrophages and the release of TNF (Collart et al. 1986, Heidenreich et al. 1989). The T cell dependence of the expression of TNF activity during cutaneous leishmaniasis is reminiscent of the situation in mice with cerebral malaria where T cells of the L3T4 subpopulation have been implicated in the induction of high levels of serum TNF (Grau et al. 1987).

The present study has shown that the levels of LPS-induced TNF production are different in susceptible and resistant mice infected with $L$. major, due to differences in the number of macrophages present, whereas the $L$. major-stimulated TNF activity is equally expressed in both susceptible and resistant mice. So, what role may TNF play in the pathogenesis of cutaneous leishmaniasis? Since the immune response to L. major is known to be mediated by different subsets of $T$ cells and various $T$-cell-derived lymphokines have been shown to influence the outcome of murine disease (Greil et al. 1988, Lelchuk, Graveley \& Liew 1988, Heinzel et al. 1989), the effect of TNF is likely to be connected with the a vailability of other cytokines. Interactions of TNF with various cytokines have been documented in a number of experimental systems. TNF augments the production of GMCSF by a variety of cell types (Munker et al. 1986) and it stimulates the release of IL-1 from macrophages (Dinarello et al. 1986). TNF and IFN- $\gamma$ act synergistically to induce macrophage killing of tumour cells and schistosomula of Schistosoma mansoni (Esparza et al. 1987). In view of these interactions, it seems conceivable that TNF exerts different effects in susceptible and resistant mice infected with L. major. This notion is supported by in vitro studies with macrophages stimulated with various combinations of recombinant cytokines. In combination with IFN- $\gamma$, a lymphokine produced in $L$. major-infected mice of resistant strains, TNF induced the elimination of parasites in infected macrophages, whereas it promoted parasite burden in the presence of IL-4 which is mainly expressed in susceptible mice (Bogdan et al. 1990). Thus, TNF may have both beneficial and deleterious effects on the infection with $L$. major, as it has been observed for viral meningitis (Doherty, Allan \& Clark 1989) and malaria (Clark et al. 1987, Grau et al. 1987, Taverne et al. 1987). More studies on the synergistic actions of cytokines are required in order to elucidate the cascade of events resulting in either resistance or susceptibility to cutaneous leishmaniasis. 


\section{Acknowledgements}

We would like to thank Dr G.R.Adolf, Ernst-Boehringer-Institut, Vienna, Austria, for the generous gift of recombinant mouse tumour necrosis factor. This work was supported by the Deutsche Forschungsgemeinschaft, FRG.

\section{References}

BERMUDEZ L.E.M. \& YouNG L.S. (1988) Tumor necrosis factor, alone or in combination with IL-2, but not IFN- $\gamma$, is associated with macrophage killing of Mycobacterium avium complex. Journal of Immunology 140, 3006

BeUtLer B. \& Cerami A. (1989) The biology of cachectin/TNF-a primary mediator of the host response. Annual Review of Immunology 7, 625

Beutler B.A., Milsark I.W. \& Cerami A. (1985) Cachactin/tumor necrosis factor: production, distribution and metabolic function in vitro. Journal of Immunology 135, 3972

Bogdan C., Moll, H., Solbach, W. \& Röllinghoff M. (1990) Tumor necrosis factor $\alpha$ in combination with interferon $\gamma$, but not with interleukin 4 , activates murine macrophages for elimination of Leishmania major amastigotes. European Journal of Immunology 20, 1131

Carswell E.A., Old L.J., Kassel R.L., Green S., Fiore N. \& Williamson B. (1975) An endotoxin-induced serum factor that causes necrosis of tumors. Proceedings of the National Academy of Sciences of the USA 72, 3666

Clark I.A., Cowden W.B., Butcher G.A. \& Hunt N.H. (1987) Possible roles of tumor necrosis factor in the pathology of malaria. American Journal of Pathology 129, 192

Collart M.A., Belin D., Vassalli J.-D., DeKossodo S. \& Vassalli P. (1986) $y$-Interferon enhances macrophage transcription of the tumor necrosis factor/cachectin, interleukin 1 , and urokinase genes, which are controlled by short-lived repressors. Journal of Experimental Medicine 164, 2113

Cross A.S., Sadoff J.C., Kelly N., Bernton E. \& Gemski P. (1989) Pretreatment with recombinant murine tumor necrosis factor $\alpha /$ cachectin and murine interleukin 1 protects mice from lethal bacterial infection. Journal of Experimental Medicine 169, 2021

DeTitto E.H., Catterall J.R. \& Remington J.S. (1986) Activity of recombinant tumor necrosis factor on Toxoplasma gondii and Trypanosoma cruzi. Journal of Immunology 137, 1342

Dinarello C.A., Cannon J.G., Wolff S.M., Bernheim H.A., Beutler B., Cerami A., Figari I.S., PALladino JR. M.A. \& O'CONNOR J.V. (1986) Tumor necrosis factor (cachectin) is an endogenous pyrogen and induces production of interleukin 1. Journal of Experimental Medicine 163, 1433

DoherTy P.C., AlLAN J.E. \& ClaRK I.A. (1989) Tumor necrosis factor inhibits the development of viral meningitis or induces rapid death depending on the severity of inflammation at time of administration. Journal of Immunology 142, 3576

Esparza I., MänNel D., Ruppel A., FAlK W. \& Krammer P.H. (1987) Interferon- $\gamma$ and lymphotoxin or tumor necrosis factor act synergistically to induce macrophage killing of tumor cells and schistosomula of Schistosoma mansoni. Journal of Experimental Medicine 166, 589

Grau G.E., Fajardo L.F., Piguet P.-F., Allet B., Lambert P.-H. \& Vassalli P. (1987) Tumot necrosis factor (cachectin) as an essential mediator in murine cerebral malaria. Science $\mathbf{2 3 7}$, 1210

Greil J., Bodendorfer B., Röllinghoff M. \& Solbach W. (1988) Application of recombinant granulocyte-macrophage colony-stimulating factor has a detrimental effect in experimental murine leishmaniasis. European Journal of Immunology 18, 1527

Handman E., Ceredig R. \& Mitchell G.F. (1979) Murine cutaneous leishmaniasis: disease patterns in intact and nude mice of various genotypes and examination of some differences between normal and infected macrophages. Australian Journal of Experimental Biology and Medical Science 57, 9

Haranaka K., Satomi N. \& Sakural A. (1984) Differences in tumour necrosis factor productive ability among rodents. British Journal of Cancer 50, 471 
Havell E.A. (1987) Production of tumor necrosis factor during murine listeriosis. Journal of Immunology 139, 4225

Heidenreich S., Gong J.-H., Schmidt A., Nain M. \& Gemsa D. (1989) Macrophage activation by granulocyte/macrophage colony-stimulating factor. Priming for enhanced release of tumor necrosis factor- $\alpha$ and prostaglandin $E_{2}$. Journal of Immunology 143, 1198

Heinzel F.P., Sadick M.D., Holaday B.J., Coffman R.L. \& Locksley R.M. (1989) Reciprocal expression of interferon or interleukin 4 during the resolution or progression of murine leishmaniasis. Evidence for expansion of distinct helper $T$ cell subsets. Journal of Experimental Medicine 169, 59

HoCKertz S., DECKer T., KIDERLEN A.F. \& BACCARINI M. (1986) A method to isolate parasitized macrophages from spleen of Leishmania donovani-infected mice. Immunobiology 173, 246

Kindler V., Sappino A.-P., Grau G.E., Piguet P.-F. \& Vassalli P. (1989) The inducing role of tumor necrosis factor in the development of bacterial granulomas during BCG infection. Cell 56, 731

KongshaVN P.A.L. \& GHadiRIan E. (1988) Enhancing and suppressive effects of tumour necrosis factor/cachectin on growth of Trypanosoma musculi. Parasite Immunology 10, 581

LelchUK R., GRAVeley R. \& LIEW F.Y. (1988) Susceptibility to murine cutaneous leishmaniasis correlates with the capacity to generate interleukin 3 in response to Leishmania antigen in vitro. Cellular Immunology 111, 66

LouIS J. \& MiLoN G., eds. (1987) Immunobiology of experimental leishmaniasis. Annales de I'Institut Pasteur/Immunology 138, 737

MODABBER F. (1987) A model for the mechanism of sensitivity of BALB/c mice to L. major and premunition in leishmaniasis. Annales de l'Institut Pasteur/Immunology 138, 781

Munker R., Gasson J., Ogawa M. \& Koeffler H.P. (1986) Recombinant human TNF induces production of granulocyte-monocyte colony-stimulating factor. Nature 323, 79

Nakane A., Minagawa T. \& Kato K. (1988) Endogenous tumor necrosis factor (cachectin) is essential to host resistance against Listeria monocytogenes infection. Infection and Immunity 56,2563

OKuno T., Takagaki Y., PluzNik D.H. \& Djeu J.Y. (1986) Natural cytotoxic (NC) cell activity in basophilic cells: release of NC-specific cytotoxic factor by IgE receptor triggering. Journal of Immunology 136, 4652

Scuderi P., Lam K.S., Ryan K.J., Petersen E., Sterling K.E., Finley P.R., Ray C.G., Slymen D.J. \& SALMON S.E. (1986) Raised serum levels of tumour necrosis factor in parasitic infections. Lancet ii, 1364

Silva C.L. \& Foss N.T. (1989) Tumor necrosis factor in leprosy patients. Journal of Infectious Diseases 159, 787

SOlbaCH W., Forberg K. \& RÓllinghoff M. (1986a) Effect of T lymphocyte suppression on the parasite burden in Leishmania major-infected, genetically susceptible BALB/c mice. Infection and Immunity 54, 909

Solbach W., Forberg K., Kammerer E., Bogdan C. \& Röllinghoff M. (1986b) Suppressive effect of cyclosporin A on the development of Leishmania tropica-induced lesions in genetically susceptible BALB/c mice. Journal of Immunology 137, 702

Tada H., Shiho O., Kuroshima K., Koyama M. \& Tsukamoto K. (1986) An improved colorimetric assay for interleukin 2. Journal of Immunological Methods 93, 157

TARLETON R.L. (1988) Tumour necrosis factor (cachectin) production during experimental Chagas' disease. Clinical and Experimental Immunology 73, 186

TaVerne J., TA Vernier J., Fiers W. \& Playfair J.H.L. (1987) Recombinant tumour necrosis factor inhibits malaria parasites in vivo but not in vitro. Clinical and Experimental Immunology 67, 1

TITUS R.G., SHERry B. \& CERAMI, A. (1989) Tumor necrosis factor plays a protective role in experimental murine cutaneous leishmaniasis. Journal of Experimental Medicine 170, 2097

W Aage A., Halstensen A. \& Espevik T. (1987) Association between tumour necrosis factor in serum and fatal outcome in patients with meningococcal disease. Lancet $\mathbf{i}(8529), 355$

WIRTH J.J. \& KIERSZENBAUM F. (1988) Recombinant tumor necrosis factor enhances macrophage destruction of Trypanosoma cruzi in the presence of bacterial endotoxin. Journal of Immunology 141, 286

WOOD P.R. \& CLARK I.A. (1984) Macrophages from Babesia and malaria-infected mice are primed for monokine release. Parasite Immunology 6, 309 